
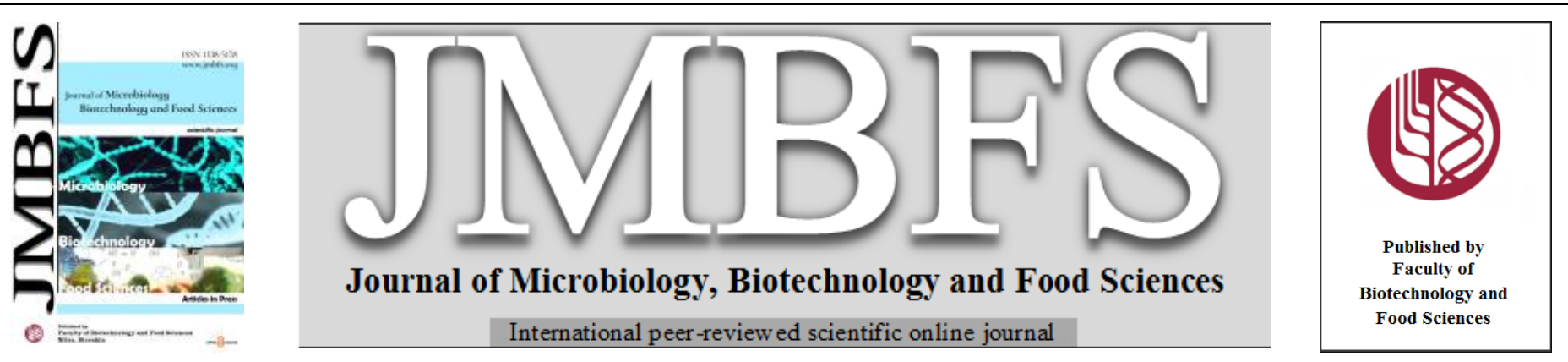

\title{
MICROPROPAGATION AND ORGANOGENESIS OF ASTROPHYTUM ASTERIAS (ZUCC.) LEM. (CACTACEAE JUSS.), BLOSSFELDIA LILIPUTIANA WERDERM. AND STROMBOCACTUS DISCIFORMIS (DC.) BRITTON \& ROSE
}

\author{
Roman Ivannikov ${ }^{1}$, Oksana Lobova ${ }^{* 2}$, Natalia Ivannikova ${ }^{1}$, Iryna Krasnienkova ${ }^{1}$ \\ Address(es): Doctor in Biological Sciences, Roman Ivannikov \\ ${ }^{\prime}$ M. M. Hryshko National Botanical Garden, Department of Tropical and Subtropical plants, laboratory of biotechnology of plants, Timiriaziev str., 1, 01014, Kyiv, \\ Ukraine, +038442852647. \\ ${ }^{2}$ National University of Life and Environmental Sciences of Ukraine, the chair of Ecobiotechnology and biodiversity, Heroiv Oborony str.13, 03041 Kyiv, Ukraine, \\ +380445278517 .
}

*Corresponding author: Lobova_o@ nubip.edu.ua

https://doi.org/10.55251/jmbfs.2201

\section{ARTICLE INFO}

Received 11. 10. 2019

Revised 10. 12. 2021

Accepted 22. 12. 2021

Published 1. 4. 2022

Regular article

open ${ }_{\text {ACCESS }}$

\section{ABSTRACT}

The research reveals results of the creation of sterile cultures and micropropagation of the species of three unique genera of Cactaceae: Astrophytum asterias (Zucc.) Lem. (I CITES); Blossfeldia liliputiana Werderm. (II CITES); Strombocactus disciformis (DC.) Britton \& Rose. (I CITES). The solutions for sterilization were selected, the time of sterilization, and the sterilization procedure of seeds was approbated. The expedience of usage of stems of juvenile plants grown in vitro for propagation of these species of cacti was proved. The possibility of an obtaining of the necessary quantity of plant material by the way of indirect organogenesis is shown. The proper content of nutrient media and favourable conditions of the cultivation for all stages of the micropropagation were approved.

Keywords: in vitro, Astrophytum asterias, Blossfeldia liliputiana, Strombocactus disciformis

\section{INTRODUCTION}

The large-scale destruction of the primary plant cover and rapid reduction of biodiversity of an aborigine flora is leading now to catastrophically intensive extinction of endemic and rare species of plants and animals. The threat of destruction of species and ecosystems has never been so greatly topical. This issue has particular importance in the field of conservation and regeneration rare species of world flora. The question is of great importance for Ukraine too as far as the Convention on Biological Diversity was ratified by Verkhovna Rada of Ukraine on November 29, 1994 (http://zakon1.rada.gov.ua).

State botanical institutions of Ukraine have several ones of the biggest collections of succulent plants in Eastern Europe. The genus of Cactaceae is one of the bigges ones of Angiosperms, the species of which inhabit arid areas of New World. The distribution of cacti on the American continents is not uniform. The most of them are concentrated along the mountains of the coastline of Pacific Ocean in desert and semi-desert zones. From South and Central America, cacti distributed to North America, where they have formed secondary center of species diversity (Borysenko, 1986)

A lot of species of the genus have a great importance in human life. Cacti are ornamental plants; they have very unusual form and have been being popular for long time as objects convenient for collections. In fact, a great part of species of Cactaceae are in the danger of extinction or they exist only in collections. These are the reasons of the permanent interest to plants of this genus.

Basing on the situation described above, the usage of the method of micropropagation currently gives the real possibilities for biology studying, useful properties, and conservation of biodiversity of this group of plants. There are many studies of propagation of cacti by the method of the sterile cultures (Vyskot, et al, 1984; Holder, et al., 1984; Ault, et al., 1987; Clayton, et al., 1990; Oliveira, et al., 1995; Batov, 2001; Popovs, 2004; Cherevchenko et al., 2008). However, considering the number of individuals of the genus and rapid destruction of ecosystems by human, a significant part of species of the genus that demands protection remains behind the attention of scientists.

The objects of our study were three endangered species of rare cacti of different genera.

Astrophytum asterias (Zucc.) Lem. is one of the six species of its genus; the populations of the species are at risk of extinction. At the beginning, plants could be found in the USA (Texas, Rio Grande valley) and in Mexico (Tamaulipas, Nuevo Leon). The general habitat is significantly segmented; its area is approximately $2000 \mathrm{~km}^{2}$ (http://www.llifle.com). The habitat of populations was usually located $50-200 \mathrm{~m}$ a. s. 1. A great part of primary area of inhabitance of $A$ asterias is destroyed by agriculture and is caused also by resettlement of the invasive rabbit population (Texas, Tamaulipas). At present, it is known that this species inhabits an area near Rio Grande. Several areas are in Mexico, in northern and in southern parts from Ciudad Victoria. It is possible that A. asterias is preserved in Nuevo Leon state. The general number of individuals of $A$. asterias in the nature in the USA and Mexico is estimated as 5000. A. asterias belongs to I Appendix of the CITEC convention. According to the gradation IUCN A. asterias belongs to the vulnerable species (Vulnerable B1ab (ii,iii,v) ver 3.1) (http://www.iucnredlist.org).

In the nature the representatives of the species often grow on muddy alluvial soils (Borysenko, 1986), on hills, more often in dents and along the dry watercourses, on the muddy alluvial loams and saline marshes or limestone clay in steppe, on the pastures and semi-deserts. The climate of the region of inhabitance is rather arid; the precipitations are less than $500 \mathrm{~mm}$ in a year. The representatives of A. asterias are mainly distributed in shadows of another plants or rocks, in grass, and on the edge of shrubs. Usually the stem is almost fully immersed in soil, at the top is often covered by sand. Its color is the same as the color of the closest environment (http://www.llifle.com). In the cultures the stem has grass-green color or darkgreen color, it is dorsiventrally flattened, round-shaped, can reach $10 \mathrm{~cm}$ in diameter, it has no thorns. In the nature and in culture, the main way of reproduction is the seed reproduction. The fertilization of plants occurs as allogamy. The vegetative reproduction can proceed but extremely rare.

Blossfeldia liliputiana Werderm. is a monotypic genus of cacti (http://www.theplantlist.org) with sphere-shaped, often dorsiventrally flattened stem that can reach $3 \mathrm{~cm}$ in diameter. Currently, there are reasons for considering it as a separate tribe Blossfeldeae (Butterworth, 2006). In the majority of scholar literature, this species is named Blossfeldia liliputana but according to the positions of International Code of Botanical Nomenclature, the right name is Blossfeldia liliputiana (McNeill, et al., 2011).

B. liliputiana originates from western Bolivia and southern part of Argentina (Anderson, 2001). Habitats of populations are sporadically located in the eastern Andes. Usually at such altitudes $(1000-2000 \mathrm{~m}$ a. s. 1.) there is a high amplitude of fluctuations of daily and year values of humidity and temperature (Barthlott, 1996). The plants are ecologically specialized, there are not many of the representatives, they are involved in the seconds appendix of CITES (Hunt, 1999). In the nature they grow between rocks, on cliffs, often between vertical cracks of cliffs, filled with soil. The representatives of species can stand strong dehydration almost full drying, and then recovering after fog or rain. 
In generative individuals of $B$. Liliputiana several white flowers with diameter of $0,9 \mathrm{~cm}$ form in an acropetal manner. The flowering proceeds $2-5$ days. The plants of this species actively form adventive sprouts. The main root is strong, contractive, and turnip-shaped. Areolas on stems have no ribbing, they are covered with hairs, and have no spines.

There is B. liliputiana cultivated but the ex situ growing is complicated and demands special knowledge and right agrotechnical approaches. That is why mostly in collections $B$. liliputiana grows on the rootstock which has a negative effect on its appearance and shifts phenological phases.

Strombocactus disciformis (DC.) Britton \& Rose is a monotypic species of the genus (Shyrokobokova et al., 2003) with one subspecies: S. disciformis subsp. esperanzae Glass \& S. Arias. (syn. S. pulcherrimus Halda). The species is endemic of Mexico, distributed in Guanajuato state, Hidalgo, and Queretaro. Plants grow on clay deposits and on shale, often along the dry watercourses. A few populations inhabit locations at the altitude of $1000-1600 \mathrm{~m}$ a. s. 1. Because of the limitations of the habitat, (under $4500 \mathrm{~km}^{2}$ - the general square of 19 locations) S. disciformis is added to the IUCN Red List of Threatened Species, the first appendix of CITEC Convention and National List of endangered plant species in Mexico (https://cites.org). Populations of S. disciformis suffer permanently of illegal gathering.

The stem of generative plants is greyish green, disciform, $8 \mathrm{~cm}$ in diameter. The main root is strong, turnip-shaped, mature plants are strongly immersed in the soil. Ribs are divided into tetrahedral, flat; areolas are tightly located. Central spines are absent. Radial spines are only on young areolas. The flowers have cream color; they are under $3 \mathrm{~cm}$ in diameter and appear in the spring in the apical part of the sprout.

Application of biotechnology will make possible preserving of rare and endangered species of cacti. However, the information of particularities of morphogenesis and organogenesis of cacti in vitro is absent.

The purpose of our study was to create sterile tissue cultures, to research specificities of the organogenesis on the initial stages of the ontogenesis, and approbation of the micropropagation procedure of the representatives of A. asterias (Zucc.) Lem., B. liliputiana Werderm., and S. disciformis (DC.) Britton $\&$ Rose (Cactaceae Juss.)

\section{MATERIAL AND METHODS}

For carrying out biotechnological researches, we selected seeds from reproductive plants of collective greenhouses of National botanical garden of the National Academy of Sciences of Ukraine. Plants of natural species were used in the work - forms and cultivars of experimental taxa were not used in the experiment.Plants were grown in the conditions of passive (in greenhouse) and active (in the laboratory of tissue cultivating) experiments. According to the demands of plants, generative individuals were grown in greenhouses with proper parameters of temperature (for vegetative phase it is $20-35^{\circ} \mathrm{C}$, for the dormancy phase it is 15 $24^{\circ} \mathrm{C}$ ). The illumination in the greenhouses is natural without additional artificial light. The light mode from November to January was 1500 lx, from December to April its value was from 2500 to 4000 lx, from May to August - from 7000 to 7500 $1 \mathrm{x}$, in September to October - from 3500 to $5000 \mathrm{~lx}$, the value of humidity was 70 $90 \%$.

In the conditions of sterile cultures, plants of experimental species were cultivated in Erlenmeyer flasks that had a volume of $250 \mathrm{ml}$. The flasks with plants were putted in the laboratory of tissue cultures on glass shelves under the artificial illumination (the value of intensity was $2000 \mathrm{~lx}$, photoperiod was 16 hours). The temperature was $22-26^{\circ} \mathrm{C}$, relative humidity was $70 \%$. Plants were cultivated on agar nutrient media, the basis of which was the content of Murashige and Skoog medium (MS) (Murrashige and Skoog, 1962), Pierik medium $\left(\mathrm{P}_{2}\right)$ (Pierik, 1987). For calusogenesis induction, the growth factors were added, such as: 2,4 D, 6 benzylaminopurine (BAP) in different concentrations. As a control a nutrient medium without growth factors was used.

The observations of morphogenesis of representatives of the experimental species were carried out with microscopes NBS-9, Carl Zeiss Jena NU. The document fixation of the growth and development stages were performed by making photos (photo cameras Canon PowerShot G5, Nikon D90). During the studying of different stages of morphogenesis of the experimental species, the objects were prepared under the binocular magnifying glass. The measuring of morphometrical parameters was performed via light MBI-15 microscope and eyepiece of micrometer $(\times 16 ; \times 18)$

Depending on the origin of the plant material, the type of solution for sterilization and the time of sterilization were specifically selected. As solutions for sterilization the following ones were used: ethanol solution $70 \%$, (Medasept, Ukraine), Thimerosal solution $0.01 \%$ (Merck, Germany), Domestos (Unilever Madyarorszag Kft., Hungury), $\mathrm{H}_{2} \mathrm{O}_{2}$ solution $10 \%$ (Medasept, Ukraine) which make the plant material free from bacterial and fungal diseases.

Plant material was sterilized in laminar flow cabinet in specific silk containers Intact plant material was sterilized in selected solutions, than they were transported in distilled water and washed 3-4 times. After the sterilization containers were dried in sterile filter paper.

Nutrient media was sterilized in autoclave under the pressure of $1 \mathrm{~atm}$. for 20-22 min. Additional materials - hydrophilic cotton, little bags, filter paper, paper envelops, instruments, vessels, Petri dishes, tubes with water - were sterilized for an hour in autoclave under the pressure of $2 \mathrm{~atm}$.

Each set of experiments was carried out three times in ten replicas. The regenerative potential of sterile cultures of explants, for each genotype was considered (quantity of conglomerates of calluses which produced regenerated organisms, the general quantity is $100 \%$ ).

Statistical analyses

The mathematical analyses of data were performed in the Statistica 6.0 program.

\section{RESULTS AND DISCUSSION}

In this study explants were selected according to the traditional for Cactaceae principles of selection (Cherevchenko, at al., 2008). For this purpose, meristems of growth centers or other tissues of different parts of the stem were utilized. The tissues of generative plants and seedlings, obtained in sterile environment or seed germs were used. Further, as a basis for micropropagation solid callus of primary or secondary origin can be used.

As primary explants for micropropagation of experimental species, the stems of seedlings, obtained from sprouted seeds in sterile environment, were used. The sprouting of seeds of all three species was rather satisfactory and reached $60-75 \%$ in this study.

The effective scheme of disinfection was approbated in empirical way. In our experiment, the scheme of sterilization was following: ethanol solution $70 \%-0,5$ min; sterile distillated water (SD) $-5 \mathrm{~min}$; thimerosal $0,1 \%-16 \mathrm{~min}$; SD $-10 \mathrm{~min}$; $\mathrm{SD}-10 \mathrm{~min}$; Domestos - $8 \mathrm{~min}$; $\mathrm{SD}-10 \mathrm{~min} ; \mathrm{H}_{2} \mathrm{O}_{2}$ solution $10 \%$ - $10 \mathrm{~min}$; $\mathrm{SD}$ $10 \mathrm{~min}$. Under such conditions, sequence, and time of sterilization, we have obtained $100 \%$ pure initial plant material, and one more sterilization which some authors recommend to carry out (Batov, 2001) we have not performed. Such sterilization sequence has made the plant material free of endogenous and exogenous infection.

From the beginning, the seeds were putted on the agar MS medium, modified with additional $250 \mathrm{mg} / \mathrm{l}$ of activated carbon (AC). The first signs of sprouting we have noticed on the 3-5 day for all three species (Figure 1a). In a few weeks, the stems of seedlings become green, on the top several initials of leaves were grown and on the basal part a root was formed. Than seedlings actively produced biomass (Figure $1 b$, Figure 2a). The first planting was carried out in three months after the beginning of cultivating. The stems of the part of seedlings were cutted perpendicular to the axis of growth in discs of 3-4 $\mathrm{mm}$ in diameter. The discs were putted on MS medium ( $+250 \mathrm{mg} / \mathrm{l}$ of $\mathrm{AC}$ and $5 \mathrm{mg} / \mathrm{l}$ of BAP). It was shown that production of callus proceeds more active in case of violation of polarity of discs, that occurs when we putted fragments with upper part to the medium plane $\left(+180^{\circ}\right)$, (Figure $\left.1 \mathrm{c}\right)$.
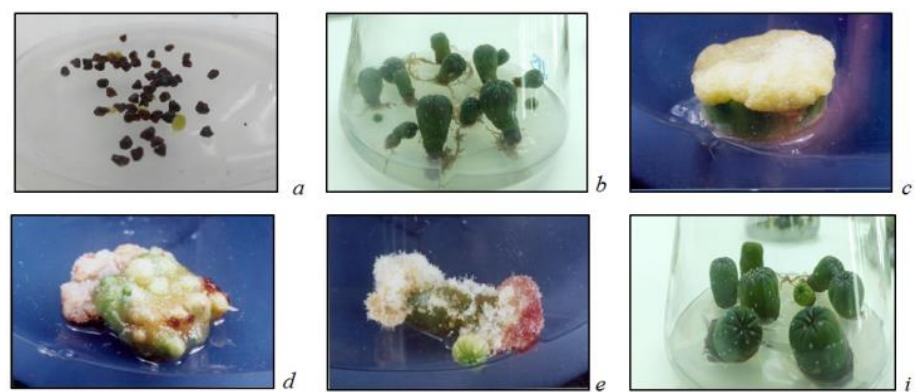

Figure 1 Sterile culture of Astrophytum asterias (Zucc.) Lem.: $a$ - sprouting of sterilized seeds on the nutrient medium; $b$ - seedlings suitable for production of callus; $c$ - formation of primary morphogenic callus on stem discs (light); $d-$ hemogenesis in callus tissue of $A$. asterias (light); $e$ - formation of friable nonmorphogenic callus of distinct sprouts (light); $i$ - regenerated plants suitable for planting in substrate.

During the experiment, we studied the influence of light on kallusogenesis. It was shown that in the dark the proliferation of callus does not occur, independent of the orientation of primary explants (Table 1). But under the light conditions, the hemogenesis occurred simultaneously with the callus production (Figure 2d, 3d) The similar results we have observed when cultivating stem explants on the Pierik medium, but on this medium, the process of callusogenesis prevail the hemogenesis.

Table 1 The frequency of primary morphogenic callus production (FPCP) from stem discs in different conditions of cultivation *

\begin{tabular}{lcccc}
\hline \multirow{2}{*}{ Taxon name } & \multicolumn{2}{c}{ FPCP, \% } & \multicolumn{2}{c}{$\begin{array}{c}\text { FPCP, space } \\
\text { orientation, \%** }\end{array}$} \\
\cline { 2 - 5 } & light & dark & norm & $\mathbf{+ 1 8 0}^{\circ}$ \\
\hline Astrophytum asterias & $56 \pm 1.45$ & 0 & $54 \pm 2.4$ & $76 \pm 3.2$ \\
\hline Blossfeldia liliputiana & $64,5 \pm 2.2$ & 0 & $63,5 \pm 3.1$ & $81 \pm 2.6$ \\
\hline Strombocactus disciformis & $52 \pm 1.8$ & 0 & $51,5 \pm 2.5$ & $68 \pm 2.7$ \\
\hline
\end{tabular}

*nutrient medium - basic content MS with $250 \mathrm{mg} / \mathrm{l} \mathrm{AC}$ and $5 \mathrm{mg} / \mathrm{l}$ of BAP; **in the light 

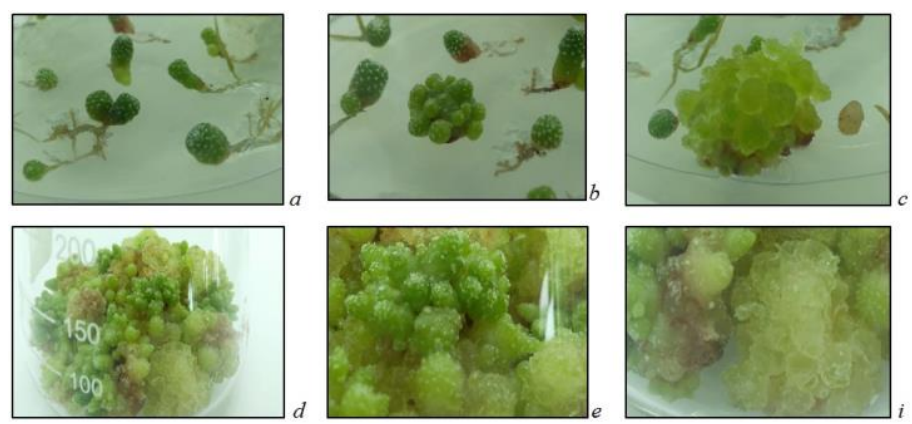

Figure 2 Sterile culture of Blossfeldia liliputiana Werderm.: $a$ - seedlings of $B$. Liliputiana on the surface of the nutrient medium; $b$ - formation of adventive sprouts; $c$ - the beginning of formation of primary nonmorphogenic callus (light); $d, e-$ hemogenesis in callus tissue of $B$. liliputiana; $i$ - formation of friable, nonmorphogenic callus.
The important and complicated problem by designing of systems of plant regeneration is the induction of morphogenic callus and the following formation of shoots by the indirect organogenesis. It is well-known that cells of callus actively divide and in definite conditions they transit into differentiation process, that is organized growth and microshoots formation. The main condition by this is the presence of exogenous growth factors in the nutrient medium (Butenko, 1999; Bhojwani, Dantu, 2013).

We have studied the complex influence of phytohormone content of the nutrient medium on the regeneration processes and following organogenesis of sterile tissues of the experimental cacti species by the same conditions of cultivation (Table 2). As the basic nutrient medium, we used the MS medium with addition of $250 \mathrm{mg} / \mathrm{l} \mathrm{AUX}$.

Table 2 The combined influence of plant growth factors on regeneration processes and the following organogenesis of conglomerates of callus of the studied species of Cactaceae*

\begin{tabular}{|c|c|c|c|c|c|c|c|}
\hline \multirow{2}{*}{$\begin{array}{l}\text { 2,4-D, } \\
\mathrm{mg} / \mathrm{l}\end{array}$} & \multirow{2}{*}{$\begin{array}{l}\text { BAP, } \\
\mathbf{m g} / \mathbf{l}\end{array}$} & \multicolumn{2}{|c|}{ Astrophytum asterias (Zucc.) Lem. } & \multicolumn{2}{|c|}{$\begin{array}{l}\text { Blossfeldia liliputiana } \\
\text { Werderm. }\end{array}$} & \multicolumn{2}{|c|}{$\begin{array}{l}\text { Strombocactus disciformis (DC.) } \\
\text { Britton \& Rose. }\end{array}$} \\
\hline & & 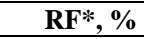 & AQR**, шт. & RF, \% & AQR **, pes. & RF, \% & AQR**, pcs. \\
\hline \multirow{5}{*}{-} & - & 10 & $1.0 \pm 0.05$ & 8 & $1.3 \pm 0.08$ & 12 & $2.1 \pm 0.08$ \\
\hline & 0.5 & 53 & $2.6 \pm 0.12$ & 50 & $2.8 \pm 0.13$ & 58 & $3.6 \pm 0.13$ \\
\hline & 1.0 & 76 & $3.2 \pm 0.27$ & 63 & $2.9 \pm 0.12$ & 76 & $3.7 \pm 0.12$ \\
\hline & 1.5 & 64 & $3.0 \pm 0.21$ & 70 & $2.6 \pm 0.34$ & 67 & $2.4 \pm 0.34$ \\
\hline & 2.0 & 57 & $2.5 \pm 0.21$ & 54 & $2.2 \pm 0.30$ & 57 & $1.9 \pm 0.30$ \\
\hline \multirow{5}{*}{0.1} & - & 13 & $1.2 \pm 0.06$ & 14 & $1.1 \pm 0.02$ & 13 & $1.1 \pm 0.02$ \\
\hline & 0.5 & 38 & $1.2 \pm 0.06$ & 42 & $1.0 \pm 0.04$ & 44 & $1.0 \pm 0.04$ \\
\hline & 1.0 & 69 & $2.2 \pm 0.27$ & 72 & $1.9 \pm 0.11$ & 69 & $2.8 \pm 0.11$ \\
\hline & 1.5 & 24 & $1.4 \pm 0.11$ & 27 & $1.4 \pm 0.09$ & 37 & $1.6 \pm 0.09$ \\
\hline & 2.0 & 17 & $1.5 \pm 0.12$ & 12 & $1.2 \pm 0.02$ & 22 & $1.2 \pm 0.02$ \\
\hline \multirow{5}{*}{0.5} & - & 0 & 0 & 0 & 0 & 12 & $1.0 \pm 0.05$ \\
\hline & 0.5 & 13 & $1.4 \pm 0.08$ & 18 & $1.1 \pm 0.07$ & 18 & $1.0 \pm 0.07$ \\
\hline & 1.0 & 15 & $1.2 \pm 0.07$ & 18 & $1.0 \pm 0.04$ & 18 & $1.4 \pm 0.04$ \\
\hline & 1.5 & 0 & 0 & 0 & 0 & 8 & $1.0 \pm 0.02$ \\
\hline & 2.0 & 0 & 0 & 0 & 0 & 0 & 0 \\
\hline \multirow{5}{*}{1.0} & - & 0 & 0 & 0 & 0 & 0 & 0 \\
\hline & 0.5 & 11 & $1 \pm 0.03$ & 0 & 0 & 0 & 0 \\
\hline & 1.0 & 0 & 0 & 0 & 0 & 0 & 0 \\
\hline & 1.5 & 0 & 0 & 0 & 0 & 0 & 0 \\
\hline & 2.0 & 0 & 0 & 0 & 0 & 0 & 0 \\
\hline
\end{tabular}

*RF - regeneration frequency (quantity of conglomerates of callus that have formed regenerated sprouts, the general amount - $100 \%$ );

**AQR - average quantity of regenerated sprouts for one callus conglomerate $(5 \times 5 \mathrm{~mm}) ; *$ - the arithmetic mean value and standard deviation are shown. The duration of experiment is 90 days

In conclusion, we have shown that, in the same cultivation conditions on the basic nutrient medium MS with $250 \mathrm{mg} / \mathrm{l} \mathrm{AU}$, the final role in differentiation process and the following organogenesis belongs to hormonal content of the nutrient medium. The all three studied species have similar trends, as we noticed; the difference was only in quantitative characteristics. We have defined that on the nutrient medium with addition of $1 \mathrm{mg} / \mathrm{l}$ of 2,4-D the differentiation and the following regeneration processes were suppressed. By the decreasing of concentration of 2,4-D to $0,5 \mathrm{mg} / \mathrm{l}-0,1 \mathrm{mg} / \mathrm{l}$, the regeneration frequency and the average quantity of regenerated sprouts for one callus conglomerate increased greatly.

For A. Asterias the optimal proportion of 2,4-D to BAP was 1:10. Better results were obtained by application of only BAP, however the best values of RF were obtained by the presence of 2,4-D. B. liliputiana has similar trends. For this plant we can recommend to carry out initiation of indirect organogenesis without 2,4-D. The same we can say for $S$. disciformis tissue culture: the presence of 2,4-D, especially in higher concentrations, in our research case, has suppressed the regeneration processes.

The important stage in micropropagation is the shoots rooting which depend on the content of nutrient medium. Completing of growing and rooting was carried out on standard MS medium, modified with adding of AC $(250 \mathrm{mg} / \mathrm{l})$. In some cases, we have observed formation of vitrified plants. According to our observations, such organisms are not viable and in sterile cultures we failed to obtain normal plants and remove them (Figure 3a).

The postaseptic adaptation was carried out in two ways. The first way is following: regenerated plants were dried a little in standard conditions for 1-2 days, after that they were planted into sterile substrate that consisted of equal parts of sand, perlite, and leafy soil. Also the plants without root system can be adapted; the regenerated plants actively make roots ex vitro in usual conditions. In this case, near $80 \%$ regenerated plants acclimatized successfully. The second way was the grafting of regenerated plants. With proper skills, the quantity of successfully adapted individuals was $90 \%$. They are more stable when changing the in vitro conditions into greenhouse conditions, they grow more fast and produce biomass, unlike plants of the same age with own roots. After that, they can be removed from rootstock, they can form root, and grow in usual greenhouse conditions. The success of the procedure of transplanting rootstocks into their own roots for representatives of all experimental species ranged from $95-100 \%$.
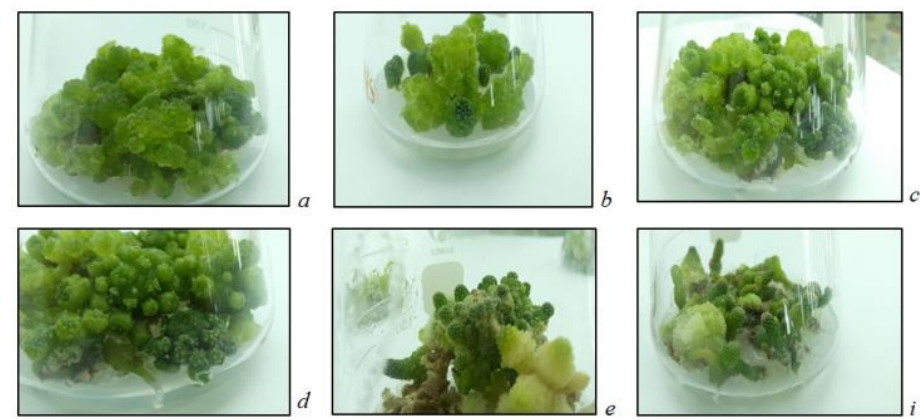

Figure 3 Sterile culture of Strombocactus disciformis (DC.) Britton \& Rose.: $a$ formation of primary nonmorphogenic callus on stem explants (light); $b, c, d$ hemogenesis in callus tissues of $S$. disciformis; $e, i-$ formation of adventive sprouts and regenerated plants of S. Disciformis suitable for ex situ planting.

\section{CONCLUSION}

The results of the experiments performed are following: the procedure of sterilization of intact plant material of A. asterias (Zucc.) Lem., B. liliputiana Werderm., and S. disciformis (DC.) Britton \& Rose was approbated and the sterile 
cultures of these species were created. The conditions and contents of nutrient media were selected for obtaining primary callus from the plants. It was found that for representatives of experimental species the light and space orientation are significant factors for primary morphogenic callus production. Than the process of callusogenesis occurs simultaneously with hemogenesis. The conditions for successful induction of morhpogenic callus formation and initiation of hemogenesis in vitro were determined. The regenerated plants of experimental species of cacti were obtained and the conditions of their postaseptic adaptation were approbated.

It was defined that the determinative factor by initiation of organogenesis in conditions of sterile cultivation is the phytohormonal content of the nutrient medium. We have shown that the high concentrations of 2,4-D can slow down or suppress the differentiation processes of callus tissues. We have defined the optimal concentrations of phytohormones for the obtaining of the maximal amount of regenerated plants of species that were studied. For Astrophytum asterias these values are 1.0-1.5 mg/l BAP, for Blossfeldia liliputiana they are $1,0 \mathrm{mg} / \mathrm{l} \mathrm{BAP}$ or $1,0 \mathrm{mg} / \mathrm{l} \mathrm{BAP:} 0,1 \mathrm{mg} / 1$ 2,4-D, for Strombocactus disciformis they are $0.5-1.0 \mathrm{mg} / \mathrm{l}$ BAP or $1,0 \mathrm{mg} / \mathrm{l} \mathrm{BAP}: 0,1 \mathrm{mg} / 1$ 2,4-D

The study was accomplished on the basis of the collection of sterile cultures of the Department of Tropical and Subtropical Plants of M. M. Hryshko National Botanical Garden that from 1999 has the status of the National heritage of Ukraine and is supported by the definite state program.

\section{REFERENCES}

Anderson E.F. The Cactus Family / E. F. Anderson // Pentland, Oregon: Timber Press. - 2001. - pp. 129 - 130. ISBN 0-88192-498-9.

Barthlott W. Ecology and morphology of Blossfeldia liliputana (Cactaceae): a poikilohydric and almost astomate succulent / W. Barthlott, St. Porembski // Bot Acta. - 1996. - 109. - p.161-166. https://doi.org/10.1111/j.14388677.1996.tb00556.x

Butterworth C. Resolving "Nyffeler's puzzle" - the intriguing taxonomic position of Blossfeldia / C. Butterworth // J. Cactus and Succulent Society of America, 2006, - № 12, p. 3-10 https://doi.org/10.2985/10700048(2006)12[3:RNPITP]2.0.CO;2

Hunt, D. 1999. CITES Cactaceae checklist. Richmond Royal Botanic Gardens, ISBN 978-0-9933113-2-1

International Code of Nomenclature for algae, fungi, and plants (Melbourne Code) adopted by the Eighteenth International Botanical Congress / J. McNeill, F.R. Barrie, W.R. Buck, V. Demoulin, W. Greuter, D.L. Hawksworth, P.S. Herendeen, S. Knapp, K. Marhold, J.Prado, W.F. Prud'homme Van Reine, G.F. Smith, J.H. Wiersema, N.J. Turland // Melbourne Australia, July 2011. - Regnum Vegetabile 154. A.R.G. Gantner Verlag KG. ISBN 978-3-87429-425-6

Murrashige, T., \& Skoog, F. (1962). A revised medium for rapid growth and bioassays with tobacco tissue culture. Physiol. Plant, 15, 473-497. https://doi.org/10.1111/j.1399-3054.1962.tb08052.x

Pierik R. L. M. In Vitro Culture of Higher Plants. Nijhoff, 1987, 344 P. https://doi.org/10.17660/ActaHortic.1988.226.1

Зайцев Н.Г. Математическая статистика в єкспериментальной ботанике. М: Нука, 1984.- 425c. ISBN 5-02-004053-3

Ильяшенко О. В., Белоус Ю. Н., Сушак Ю. П. "Уникальная энциклопедия. Кактусы.", 2003 ISBN 966-8076-11-7

Лапин Г.Ф. Биометрия. - М. : Высшая школа, 1980. - 293c. ISBN 5-06-0004716

Черевченко Т.М., Лаврентьева А.М., Иванников Р.В. Биотехнология тропических и субтропических растений in vitro. - К.: Наукова думка. -2008 -560 c. ISBN 978-966-00-0702-4.

Широбокова Д. Н. Кактуси та інші сукулентні рослини / Д. Н. Широбокова В.В. Нікітіна, М. М. Гайдаржи, К. М. Баглай // К.: Українські пропілеї, 2003. - 110 c. ISBN 966-7015-28-9

Guidelines from internet: Astrophytum asterias: https://www.iucnredlist.org/species/40961/121438670

Guidelines from internet: CACTI: http://www.llifle.com/Encyclopedia/CACTI Guidelines from internet: The plant list: http://www.theplantlist.org/tpl1.1/search?q=Blossfeldia

Guidelines from internet: CITEZ: https://cites.org/eng/app/appendices.php

Guidelines from internet: CITES and Cacti a user's guide: https://www.researchgate.net/publication/235419184 